\author{
*PG KENNEDY, \\ †ELEANOR J BELL, \\ †SHEILA A KEANE, \\ TMORAG C TIMBURY \\ * Department of Neurology, \\ Institute of Neurological Sciences, \\ Southern General Hospital, \\ Glasgow, G5I 4TF \\ †Enterovirus Reference (Scotland) \\ Laboratory, \\ Ruchill Hospital, \\ Glasgow, G20 9NB \\ †6 Quadrant Road, \\ Glasgow, G43 \\ IDepartment of Bacteriology, \\ Royal Infirmary, \\ Glasgow, G4 OSF
}

1 McCartney RA, Banatvala JE, Bell EJ. Routine use of $\mu$-antibody-capture ELISA for the serological diagnosis of Coxsackie B virus infections. J Med Virol 1986;19:205-12.

2 Pugh SF. Heterotypic reactions in a radioimmunoassay for Coxsackie B virus specific IgM. J Clin Pathol 1984;37:433-9.

3 Bell EJ, McCartney RA, Basquill D, Chaudhuri AKR. $\mu$-Antibody capture ELISA for the rapid diagnosis of enterovirus infections in patients with aseptic meningitis. J Med Virol 1986;19:213-7.

Cytopathic effects of Campylobacter pylori urease

It is now accepted that there is a close association between Campylobacter pylori and gastroduodenal disease, ${ }^{12}$ but the precise nature of the association remains unclear, and the potential pathogenic role of the organism requires investigation. Many possible virulence mechanisms merit consideration including direct toxic effects of bacterial products on cells. We investigated the action of bacteria free preparations derived from $C$ pylori on cell cultures and obtained evidence that urease may play an important part in cell damage.

Three isolates of $C$ pylori from gastric antral biopsy specimens from separate patients in this hospital were used. Organisms were grown on $10 \%$ blood agar for 48 hours, suspended in phosphate buffered

Table Titres of cytopathic effects produced by $C$ pylori preparations after 20 hours' incubation with Vero cells under different conditions

\section{Additions}

\begin{tabular}{|c|c|c|c|}
\hline Test preparation & Nil & $30 \mathrm{mM}$ urea & $30 \mathrm{mM}$ urea + serum $^{*}$ \\
\hline $\begin{array}{l}C \text { pylori } 1 \\
C \text { pylori } 2 \\
C \text { pylori } 3\end{array}$ & No cytopathic effect & $\begin{array}{l}1: 384 \\
1: 48 \\
1: 384\end{array}$ & $\begin{array}{l}1: 96 \\
1: 12 \\
1: 96\end{array}$ \\
\hline
\end{tabular}

*added at 1:32 final dilution. saline, and centrifuged at $7000 \mathrm{~g}$ for 20 minutes. The supernatants were filtered using a $0 \cdot 2 \mu \mathrm{m}$ filter and applied to established Vero cell monolayers. Cytopathic effects were then observed. ${ }^{3}$

None of the three preparations produced a clearly discernible cytopathic effect after incubation with cells over 96 hours, but when urea was added to the system $(30 \mathrm{mmol} / \mathrm{l})$, the cells rounded up within 90 minutes (table) and subsequently lysed. These effects were accompanied by a pronounced rise in $\mathrm{pH}$. The three $C$ pylori preparations contained urease, and similar cytopathic effects were obtained using Jack bean and Bacillus ureases (Sigma) in the presence of urea. A two-fold dilution series of ammonia added directly to cell monolayers resulted in the same characteristic cytopathic effect at final concentrations of $1.35 \mathrm{mmol} / \mathrm{l}$ and above. If the ammonia was pre-neutralised to give a $\mathrm{pH}$ of 7.4 the cytopathic effect was retained at concentrations of $2.7 \mathrm{mmol} / \mathrm{l}$ and above. Raising the $\mathrm{pH}$ using $\mathrm{NaOH}$ produced an entirely different cytopathic effect. These findings support the view that the cytopathic effect produced by the $C$ pylori preparations was related to the generation of ammonia by ureolytic activity and that this effect was largely independent of $\mathrm{pH}$.

The cytopathic activity of our preparations withstood a temperature of $56^{\circ} \mathrm{C}$ for 15 minutes but was abolished at $80^{\circ} \mathrm{C}$. Under the conditions used this activity was not affected by the addition of the competitive urease inhibitor thiourea, which, in contrast, did inhibit the cytopathic effect produced by the commercially available purified ureases. The addition of serum from a patient colonised with $C$ pylori and with high titres of circulating antibodies against the organism, determined by ELISA ${ }^{4}$ caused a substantial reduction in cytopathic effect titre (table). This serum had no analogous neutralising effect on the two commercially obtained ureases.

Our findings suggest that the urease activity of $C$ pylori can cause cytopathic effects by the production of ammonia. Although other workers have suggested an important role for urease $^{5}$ we have shown

directly the cytopathic potential of this activity. As we have also shown that concentrations of ammonia as low as $2.7 \mathrm{mmol} / \mathrm{l} \mathrm{can}$ produce clear cytopathic effect even at physiological $\mathrm{pH}$, it is likely that local ammonia production by this organism is sufficient to produce cell damage and result in inflammation. We conclude that the ureolytic activity of $C$ pylori may be important in the pathogenesis of gastritis and peptic ulcer.

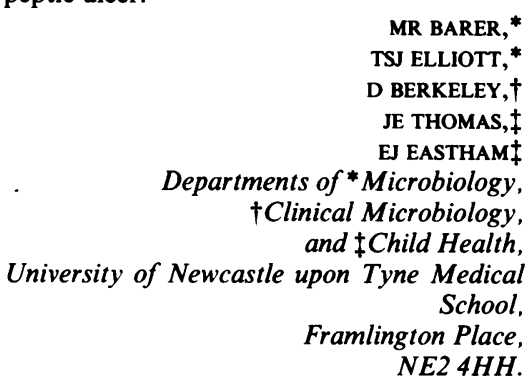

References

1 Marshall BJ. Campylobacter pyloridis and gastritis. J Infect Dis 1986;53:650-7.

2 Graham DY, Klein PD. Campylobacter pyloridis gastritis: the past the present and speculations about the future. Am J Gastroenterol 1987;82:283-6.

3 Barer MR, Millership SE, Tabaqchali S. Relationship of toxin production to species in the genus Aeromonas. J Med Microbiol 1986;22:303-9.

4 Jones DM, Eldridge J, Fox AJ, et al. Antibody to the gastric campylobacter-like organism ("Campylobacter pyloridis")-Clinical correlations and distribution in the normal population. J Med Microbiol 1986;22:57-62.

5 Hazell SL, Lee A. Campylobacter pyloridis, urease, hydrogen ion back diffusion and gastric ulcers. Lancet 1986;ii:15-17.

\title{
Other correspondence
}

\section{Brown fat and sudden death}

We were interested by the report of brown fat necrosis found in post-perinatal necropsy specimens by Stephenson and Variend.' Brown fat is a favoured substrate for various virus infections in newborn mice infected with group B Coxsackie viruses. ${ }^{2}$ Brown fat necrosis can also be produced in mice infected with some group A Coxsackie viruses, ${ }^{3}$ particularly Coxsackie A7 virus which can do so in adult cotton rats. ${ }^{4}$ It was for this 